\title{
ASTM COMMITTEE C28: INTERNATIONAL STANDARDS FOR PROPERTIES AND PERFORMANCE OF ADVANCED CERAMICS-THREE DECADES OF HIGH-QUALITY, TECHNICALLY-RIGOROUS NORMALIZATION
}

\author{
Michael G. Jenkins \\ Bothell Engineering \& Science Technologies \\ Bothell, WA, USA \\ Jonathan A. Salem \\ NASA Glenn Research Center \\ Cleveland, $\mathrm{OH}$, USA
}

\begin{abstract}
Physical and mechanical properties and performance of advanced ceramics and glasses are difficult to measure correctly without the proper techniques. For over three decades, ASTM Committee C28 on Advanced Ceramics, has developed high-quality, technically-rigorous, fullconsensus standards (e.g., test methods, practices, guides, terminology) to measure properties and performance of monolithic and composite ceramics that may be applied to glasses in some cases. These standards contain testing particulars for many mechanical, physical, thermal, properties and performance of these materials. As a result these standards are used to generate accurate, reliable, repeatable and complete data. Within Committee C28, users, producers, researchers, designers, academicians, etc. have written, continually updated, and validated through round-robin test programs, 50 standards since the Committee's founding in 1986. This paper provides a detailed retrospective of the 30 years of ASTM Committee C28 including a graphical pictogram listing of C28 standards along with examples of the tangible benefits of standards for advanced ceramics to demonstrate their practical applications.
\end{abstract}

KEYWORDS - ceramics, composites, coatings, standards, characterizations, properties, measurements.

\section{INTRODUCTION AND BACKGROUND}

The year 2016 marks the $30^{\text {th }}$ anniversary of ASTM Committee C28 "Advanced Ceramics." The establishment of C28 reflected the driving forces and visionaries of the 1980's who realized that the time had come for ceramics to become commonly recognized, used, and fabricated as an advanced engineering material along with metals; polymers and composites.

Advanced ceramics is the defined and accepted term in the United States for what are also known as engineering ceramics, structural ceramics, fine ceramics (Japan), and technical ceramics (Europe). ASTM has defined [1] an advanced ceramics as: a highly engineered, high performance, predominately non-metallic, inorganic, ceramic material having specific functional attributes. Throughout history, technological evolution has driven material performance requirements above and beyond those usually satisfied by normal engineering materials. With increasing engineering demands for advanced technology applications, materials (e.g., advanced ceramics and modern composites) are the enabling technology and, as it turns out, standards and design codes, are the enabling supporting technologies.

Prior to 1980, the primary engineering applications of ceramics involved wear-resistance, low stress, electrical insulation or some combination of these [2-4]. Even though many advanced technology applications of ceramics seem common now in the $21^{\text {st }}$ century, in the mid 1980's these were potential and not actual applications. These applications include microprocessor substrates, gas 
turbine vanes and blades, ball bearings, hip joints, ballistic armor, window panes, cutting blades, sensors, and electrolytes, to name a few. Of particularly interest for the market prognosticators were high-temperature applications such as heat engines, both reciprocating and turbines [5-14].

Recognizing the rapidly expanding applications of advanced ceramics, the Engineering Ceramics Division of the American Ceramic Society (ACerS) evolved out of the long-standing Ceramic-Metal Systems Division in 1985. Similarly, Committee C28 “Advanced Ceramics" of American Society for Testing and Materials (now ASTM International) was formed as a new standalone committee separate from a subcommittee within Committee C08 “Refractories” in 1986 [5-9].

ASTM Committee C28 has the following scope [15, 16]: the promotion of knowledge, stimulation of research and development of standards (classifications, specifications, nomenclature, test methods, guides, and practices) relating to processing, properties, characterization, and performance of advanced ceramic materials. Committee C28 works in concert with other technical committees (e.g., D30 "Composite Materials," E07 "Non Destructive Testing," E08 "Fatigue and Fracture," E28 "Mechanical Testing," F04 "Medical and Surgical Materials and Devices", and G02 "Wear and Erosion") and other national and international organizations having mutual or related interests.

Standards for monolithic and composite advanced ceramics are developed and maintained by Committee C28 [15, 16]. These standards cover methods for testing bulk properties as well as constituent (powders, fibers, etc.) properties. Thermal and physical properties, strengths and strength distributions, and performance under varying environmental, thermal, and mechanical conditions are addressed. The breadth of applications of the methods ranges from quality control through design data generation. The Committee's primary objective is the development of technically rigorous standards that are accessible to the general industrial laboratory and, consequently, are widely-accepted and used in the design, production, and utilization of advanced ceramics.

It is important to understand that ASTM International is the primary standards writing organization (SWO) for testing materials in the United States [6-9]. ASTM International is a private nonprofit corporation for the development of voluntary, full-consensus standards on the characteristics and performance of materials, products, systems, and services and for the promotion of related knowledge. The various ASTM committees accomplish this work through the efforts of volunteer experts who follow established regulations to generate a standard that is high-quality, widelyrecognized, well-accepted and generally-used. ASTM publishes six different types of standards: test method, specification, classification, practice, guide, and terminology [17]. A test method is a definitive procedure that produces test results. A specification is an explicit set of requirements to be satisfied by a material, product, system or service. A classification is a systematic arrangement or division of materials, products, systems, or services into groups based on similar characteristics such as origin, composition, properties, or use. A practice is a definitive set of instructions for performing one or more specific operation that does not include a test result. A guide is a compendium of information or series of options that does not recommend a specific course of action. Finally, terminology is a document comprising definitions of terms; explanations of symbols, abbreviations, or acronyms.

In this paper, three periods the over the three decades of existence of Committee C28 are discussed: Early Years - Direction and Growth (1986-93); Transition Years - International Harmonization (1993-2006); Present Years - Applications and Validation (2006-Today). In concluding, examples of the tangible benefits of standards for advanced ceramics are provided to demonstrate their practical applications. 


\section{ASTM Committee C28 Advanced Ceramics}

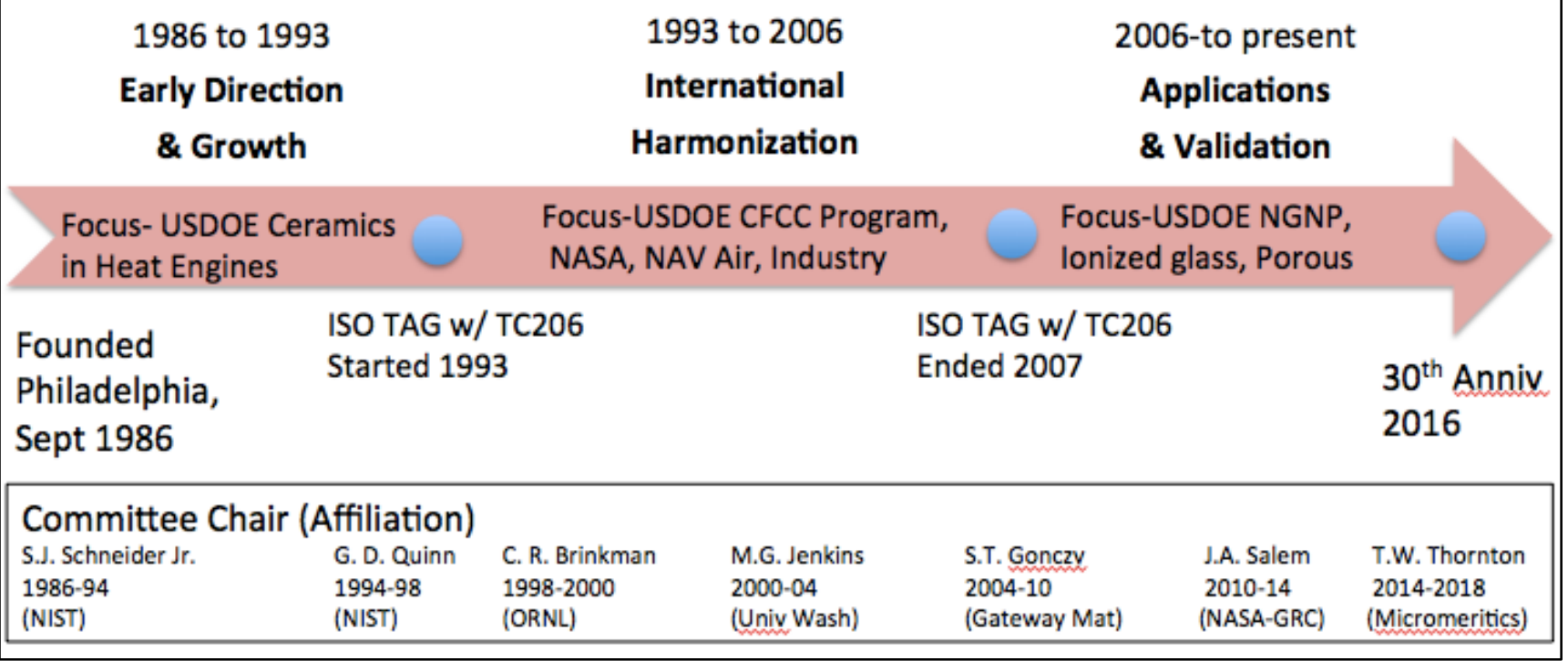

Figure 1 - Timeline for the first three decades of ASTM Committee C28

\section{DISCUSSION}

The three decades of ASTM Committee C28's activities can be divided into time periods: Formative Years; Transition Years; and Present Years as discussed in the following subsections.

\section{Committee C28: Formative Years - Early Direction and Growth (1986-93)}

At a meeting held at ASTM headquarters in Philadelphia in August 1986 and attended by over 150 interested parties, ASTM Committee C28 Advanced Ceramics was formed [7-9]. Inaugural members included a breath of participants from industry, government facilities, and universities. These members were, and still are, classified as i) users (those who use ceramic materials or products in components or devices), ii) producers (those who make ceramic materials or products), and iii) general interest (those do not have a commercial interest in ceramics or ceramic components/devices). In hindsight, it turned out, peak membership in Committee C28 was in 1986 when interest was keen and the challenging work of drafting standards and guiding them to publication through a multi-step, full-consensus balloting and approval process had yet to begin. Membership of Committee C28 from the early years through the transition years and finally to the application years is illustrated in Figure 2.

It is interesting that the early leadership of Committee C28 included organizations that had interest in the technological and commercial successes of advanced ceramics [6-9]. As examples, the inaugural chair (Samuel Schneider, Jr) and vice chair (George Quinn) of Committee C28 were affiliated with the Ceramics Division of National Institute for Standards and Technology (NIST) within the US Department of Commerce. Additionally, Charles Brinkman and Robert McClung of the Metals and Ceramics Division at Oak Ridge National Laboratory (ORNL) and US Department of Energy along with David Cranmer of NIST were the chairs of subcommittees C28.01 Properties and Performance, C28.02 Design and Evaluation and C28.07 Ceramic Composites, respectively.

The direction and, to some extent, the mission of Committee C28 were shaped by the perceived needs of programs for insertion of advanced ceramics into heat engines. Some of these programs were primarily driven and funded by US federal government agencies and addressed issues relevant to processing and characterization of ceramics as well as design with ceramics, including reliability. 


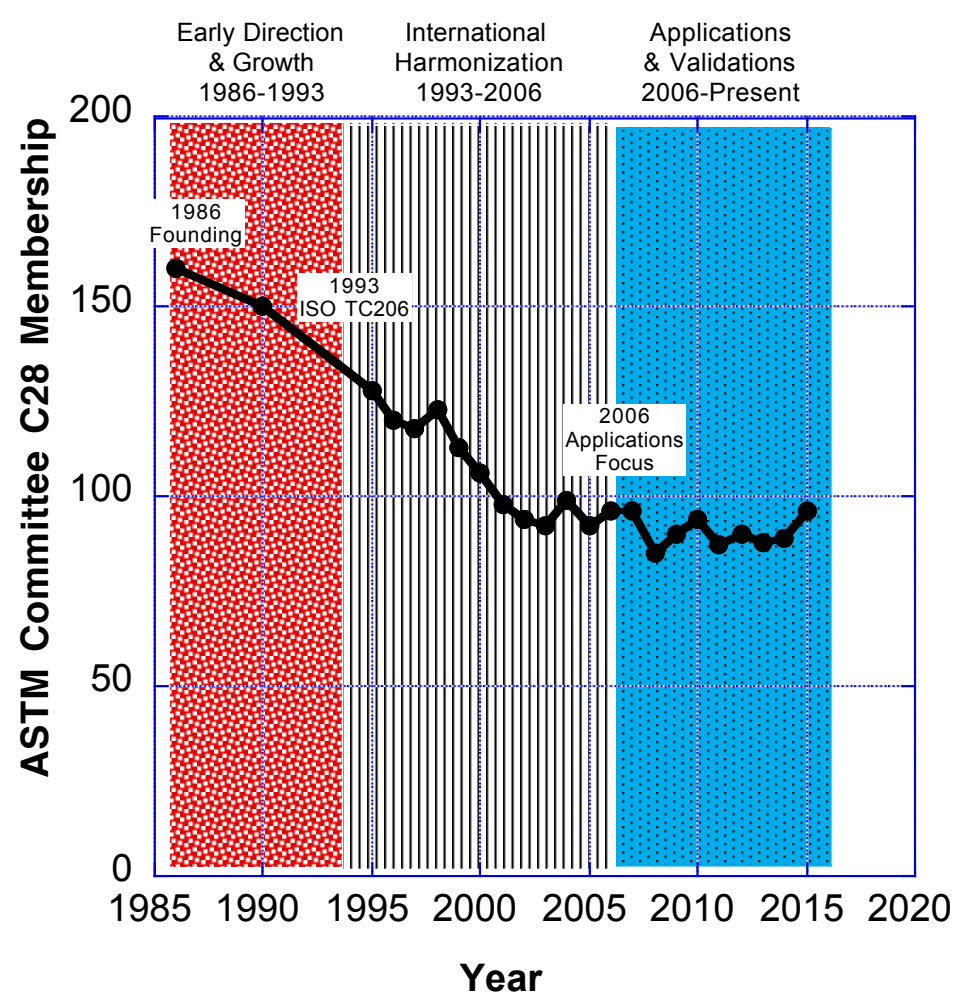

Figure 2-Membership of ASTM Committee C28 from 1986 to 2016

Three administrative committees and four technical subcommittees comprised the organization of Committee C28 in the early years, as follows:

Administrative
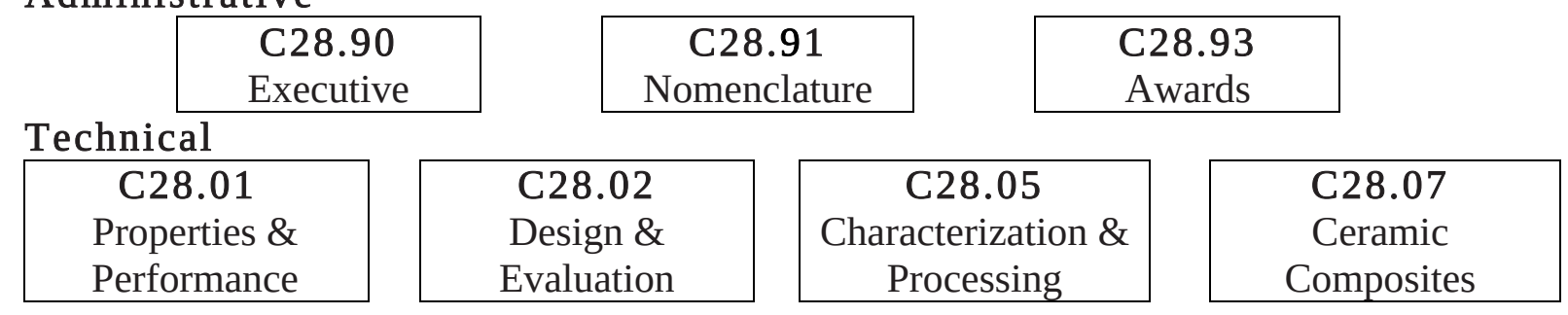

Although Committee C28 began its work in 1986, the first standard developed and approved under its jurisdiction was Test Method C1161 [18] on flexure testing at room temperature, first published in 1990 [8, 9]. Interestingly, Test Method C1161 evolved from MIL STD 1942 (MR), "Flexural Strength of Advanced Ceramics at Ambient Temperature," which had been adopted in November 1983. Many years of effort had already gone into MIL STD 1942 including error analysis, procedures for test specimen preparation, round robin testing, etc. [19]. However, the development and subsequent publication of Test Method C1161 still required much effort in refining information contained in MIL STD 1942 and reconfiguring it into an ASTM standard.

Note that the general process of developing a standard involves the following steps:

1) Establish a task group of experts (both within and outside ASTM).

2) Create a work item and prepare a draft standard.

3) Ballot the draft standard at the subcommittee level only.

4) If approved with no negative ballots, ballot the draft standard at the committee and society levels.

5) If approved at the committee levels, publish the standard as a separate or within a volume in the Annual Book of ASTM Standards. 
These steps may take six months to two years or more to complete. If negative ballots are received at any level then these must be resolved before balloting can proceed to the next level, thereby ensuring the fullconsensus approval process. Note that all ASTM standards undergo a mandatory review process every five years during which they are either reapproved or revised, so as to maintain the relevancy and currency of published standards. Standards under the jurisdiction of Committee C28 are published in Volume 15.01 in the ASTM Annual Book of Standards. Updates on the complete listing of Committee C28 standards occur regularly [16].

ASTM Standards under the jurisdiction of Committee C28 that were approved and published during its Early Years are shown in Table I.

\section{Committee C28: Transition Years - International Harmonization (1993-2006)}

During 1993, two developments occurred that substantially affected the next decade of Committee C28: i) the rise of ISO TC206 and ii) the growth of the CFCC Program and continued support of ceramics in heat engines projects in US DOE.

The first development reflected a natural evolution in standards writing organizations (SWOs) and the internationalization of standards that had evolved from the organizational level to national and/or regional levels. This evolution leads to harmonization of the various organizational/national/regional standards into one or more international standard(s) that reflect best practices, insights, methodologies and interpretations contained in these other standards. In late 1992, ISO TC206 Fine (technical, advanced) Ceramics was formally established [20]. Its first plenary meeting was held in 1994 at which Samuel Schneider of NIST (the first chair of Committee C28) presided as chair of ISO TC206, a position he held until 2003. Several major national and regional SWOs from which ISO TC206 harmonized its standards included CEN TC184 on Technical Ceramics (established in 1989) [21], ASTM C28 on Advanced Ceramics (established in 1986), JIS R on Fine Ceramics (est. in 1979), BSI RPI/13 on Technical Ceramics (est. in 1984), DIN NMP291 on Technical Ceramics (est. in 1987) to name a few. Early ISO TC206 membership included 10 participating (P) and 22 observer $(\mathrm{O})$ countries [20].

Table I - Committee C28 standards developed and published in its Formative Years (1986-93)

\begin{tabular}{|l|l|c|c|}
\hline $\begin{array}{c}\text { Number } \\
\text { (current version } \\
\text { year) }\end{array}$ & \multicolumn{1}{|c|}{ Title } & $\begin{array}{c}\text { Year } \\
\text { Approved \& } \\
\text { First } \\
\text { Published }\end{array}$ & $\begin{array}{c}\text { Current } \\
\text { Responsible } \\
\text { Subcommittee }\end{array}$ \\
\hline C1145 (2013) & Terminology on Advanced Ceramics & 1990 & C28.91 \\
\hline C1161 (2013) & $\begin{array}{l}\text { Test Method for Flexural Strength of Advanced } \\
\text { Ceramics at Ambient Temperature }\end{array}$ & 1990 & C28.01 \\
\hline C1175 (2010) & $\begin{array}{l}\text { Guide to Test Methods for Nondestructive Testing of } \\
\text { Advanced Ceramics }\end{array}$ & 1991 & C28.01 \\
\hline C1198 $\quad(2013)$ & $\begin{array}{l}\text { Test Method for Dynamic Young's Modulus, Shear } \\
\text { Modulus, and Poisson's Ratio for Advanced } \\
\text { Ceramics by Sonic Resonance }\end{array}$ & 1991 & C28.01 \\
\hline C1211 $\quad(2013)$ & $\begin{array}{l}\text { Test Method for Flexural Strength of Advanced } \\
\text { Ceramics at Elevated Temperature }\end{array}$ & 1992 & C28.02 \\
\hline C1212 $\quad(2015)$ & $\begin{array}{l}\text { Practice for Fabricating Ceramic Reference } \\
\text { Specimens Containing Seeded Voids }\end{array}$ & 1993 & C28.02 \\
\hline C1239 $\quad(2013)$ & $\begin{array}{l}\text { Strength Data and Estimating Weibull Distribution } \\
\text { Parameters for Advanced Ceramics }\end{array}$ & 1993 & \\
\hline
\end{tabular}


In order to work with ISO TC206, Committee C28 created a new subcommittee, C28.94 ISO TC206 Technical Advisory Group (TAG). Because the official US representation to ISO is through ANSI, the C28.04 TAG acted only in an advisory role to ANSI for official ISO TC206 matters. From its creation in 1993 to its dissolution in 2006, Subcommittee C28.94 introduced and refined bylaws in which technical experts were identified for various ISO TC206 efforts, relevant subcommittees balloted on various stages of ISO TC206 activities and delegates for ISO TC206 plenary meetings were selected. Of the many challenges inherent in maintaining an ANSI/ISO TAG, one of the more vexing is financial because ANSI demands an annual fee to maintain each ISO TC affiliation (this fee is paid by ASTM but charged to the relevant committee which relies on voluntary, often industrysourced, revenues) and delegates to international meetings incur travel costs that must somehow be met. Another challenge is the time commitment because in addition to advancing and maintaining its own ASTM standards with a national membership, Committee members must advance and maintain ISO standards with an international membership. Although participation of Committee C28 members in ISO TC206 was initially vigorous and productive (see Table II), the financial and time burdens along with politics within ASTM International to promote its own standards as international, led to the decision within Committee C28 to officially discontinue its direct participation in ISO TC206 and to dissolve Subcommittee C28.94 in 2006. Note that ISO TC206 continues to this day with 18 P and 13 O member countries [22].

The second development was a well-funded, broad-based program supported by US DOE and driven by industrial and aerospace applications of continuous fiber ceramic composites (CFCCs). It was recognized that CFCCs were the enabling technology for many types of advanced technologies that included chemical and petroleum refineries, next generation nuclear power, aerospace planes, gas turbines and scramjets. Because CFCCs were fabricated quite differently than monolithic ceramics and behaved quite differently (i.e., nonlinear stress strain curve indicative of a cumulative damage, fracture resistant response), unique test methods were required [23, 24]. Eventually, eleven standards for CFCCs were developed and published during this period. In addition, two symposia (see Table III) related to CFCCs were organized during this period that resulted in two STPs (STP 1309 and 1392) [25, 26]. Membership and participation in Subcommittee C28.07 Ceramic Composites grew as well.

During this same period, efforts funded by US DOE in the area of insertion of ceramics in advanced heat engines also drove development of standards for monolithic advanced ceramics. In particular, contracts for fabrication and processing of ceramics included requirements for uniaxial, uniform testing (e.g., tension and compression). Long-term performance requirements for ceramic engine components required standards for creep, slow crack growth. Many years of development finally led to a comprehensive standard for fracture toughness testing of monolithic that included three different techniques that give remarkably consistent results for a NIST-provided standard reference material (SRM 2100). These efforts also lead to two other symposia that resulted in two additional STPs for monolithic and composite ceramics (STP 1201 on life prediction/data and STP 1409 on fracture resistance) [27, 28].

Committee C28 also developed an ASTM-required, long-range plan (LRP) during this period. As part of the LRP, a new permanent subcommittee on long range planning (Subcommittee C28.95) was established. The goals contained in the first LRP for Committee C28 introduced in 2000 were as follows:

1) Maintain and update existing ASTM standards for advanced ceramics with emphasis on those that are most widely used.

2) Maintain and update existing ISO standards for advanced ceramics for which the committee has been convenor through its TAG.

3) Develop new standards for advanced ceramics that can provide support for evolving specifications, design codes and data bases

4) Develop new standards for advanced ceramics that can provide support for applications that are non structural based on user needs

5) Coordinate and disseminate information on advanced ceramics through standards, symposia and publications. 
Table II - ISO Standards developed with Committee C28 expertise and/or using relevant C28 standards

\begin{tabular}{|c|c|c|c|c|}
\hline $\begin{array}{l}\text { ISO } \\
\text { TC206 } \\
\text { Number }\end{array}$ & $\begin{array}{l}\text { Title ISO TC206 Fine } \\
\text { ceramics (advanced } \\
\text { ceramics, advanced } \\
\text { technical ceramics)- }\end{array}$ & $\begin{array}{l}\text { Year } \\
\text { Approved }\end{array}$ & $\begin{array}{l}\text { Relevant ASTM C28 } \\
\text { Standard }\end{array}$ & $\begin{array}{l}\text { ASTM C28 Project } \\
\text { Convenor/US } \\
\text { Expert }\end{array}$ \\
\hline ISO 14703 & $\begin{array}{l}\text { Sample preparation for the } \\
\text { determination of particle size } \\
\text { distribution of ceramic powders }\end{array}$ & 2000 & $\begin{array}{l}\text { C1282 Test Method for } \\
\text { Determining the Particle Size } \\
\text { Distribution of Advanced } \\
\text { Ceramics by Centrifugal Photo } \\
\text { sedimentation }\end{array}$ & $\begin{array}{l}\text { S. G. Malghan (NIST) - } \\
\text { US Expert }\end{array}$ \\
\hline ISO 14704 & $\begin{array}{l}\text { Test method for flexural strength } \\
\text { of monolithic ceramics at room } \\
\text { temperature }\end{array}$ & 2000 & $\begin{array}{l}\text { C1161 Test Method for Flexural } \\
\text { Strength of Advanced Ceramics } \\
\text { at Ambient Temperature }\end{array}$ & $\begin{array}{l}\text { G.D. Quinn (NIST) - } \\
\text { Convenor/US Expert }\end{array}$ \\
\hline ISO 14705 & $\begin{array}{l}\text { Test method for hardness of } \\
\text { monolithic ceramics at room } \\
\text { temperature }\end{array}$ & 2000 & $\begin{array}{l}\text { - C1326 Test Method for Knoop } \\
\text { Indentation Hardness of } \\
\text { Advanced Ceramics } \\
\text { - C1327 Test Method for } \\
\text { Vickers Indentation Hardness of } \\
\text { Advanced Ceramics }\end{array}$ & $\begin{array}{l}\text { G.D. Quinn (NIST) - } \\
\text { Convenor/US Expert }\end{array}$ \\
\hline ISO 15490 & $\begin{array}{l}\text { Test method for tensile strength of } \\
\text { monolithic ceramics at room } \\
\text { temperature }\end{array}$ & 2000 & $\begin{array}{l}\text { C1273 Test Method for Tensile } \\
\text { Strength of Monolithic } \\
\text { Advanced Ceramics at Ambient } \\
\text { Temperatures }\end{array}$ & $\begin{array}{l}\text { M. G. Jenkins (UW, } \\
\text { Seattle) -US Expert }\end{array}$ \\
\hline ISO 15165 & Classification system & 2001 & $\begin{array}{l}\text { C1291 Classification for } \\
\text { Advanced Ceramics }\end{array}$ & $\begin{array}{l}\text { S.J. Schneider, Jr. (NIST) - } \\
\text { Convenor/US Expert }\end{array}$ \\
\hline ISO 15733 & $\begin{array}{l}\text { Test method for tensile stress- } \\
\text { strain behavior of continuous } \\
\text { fiber-reinforced composites at } \\
\text { room temperature }\end{array}$ & 2001 & $\begin{array}{l}\text { C1275 Test Method for } \\
\text { Monotonic Tensile Behavior of } \\
\text { Continuous Fiber-Reinforced } \\
\text { Advanced Ceramics with Solid } \\
\text { Rectangular Cross-Section at } \\
\text { Ambient Temperatures }\end{array}$ & $\begin{array}{l}\text { M. G. Jenkins (UW, } \\
\text { Seattle)-Convenor/US } \\
\text { Expert }\end{array}$ \\
\hline ISO 17561 & $\begin{array}{l}\text { Test method for elastic moduli of } \\
\text { monolithic ceramics at room } \\
\text { temperature by sonic resonance }\end{array}$ & 2002 & $\begin{array}{l}\text { C1198 Test Method for } \\
\text { Dynamic Young's Modulus, } \\
\text { Shear Modulus, and Poisson's } \\
\text { Ratio for Advanced Ceramics } \\
\text { by Sonic Resonance }\end{array}$ & $\begin{array}{l}\text { S.T. Gonczy (Gateway } \\
\text { Materials Tech)-US Expert }\end{array}$ \\
\hline ISO 18757 & $\begin{array}{l}\text { Determination of specific surface } \\
\text { area of ceramic powders by gas } \\
\text { adsorption using the BET method }\end{array}$ & 2003 & $\begin{array}{l}\text { C1274 Test Method for } \\
\text { Advanced Ceramic Specific } \\
\text { Surface Area by Physical } \\
\text { Adsorption }\end{array}$ & $\begin{array}{l}\text { H. Giesche } \\
\text { (Alfred University)-US } \\
\text { Expert }\end{array}$ \\
\hline ISO 15732 & $\begin{array}{l}\text { Test method for fracture } \\
\text { toughness of monolithic ceramics } \\
\text { at room temp. by single edge } \\
\text { precracked beam (SEPB) method }\end{array}$ & 2003 & $\begin{array}{l}\text { C1421 Test Methods for the } \\
\text { Determination of Fracture } \\
\text { Toughness of Advanced } \\
\text { Ceramics }\end{array}$ & $\begin{array}{l}\text { I. Bar-on (WPI) -US } \\
\text { Expert }\end{array}$ \\
\hline ISO 17565 & $\begin{array}{l}\text { Test method for flexural strength } \\
\text { of monolithic ceramics at elevated } \\
\text { temperature }\end{array}$ & 2003 & $\begin{array}{l}\text { C1211 Test Method for Flexural } \\
\text { Strength of Advanced Ceramics } \\
\text { at Elevated Temperature }\end{array}$ & $\begin{array}{l}\text { G.D. Quinn (NIST) - } \\
\text { Convenor/US Expert }\end{array}$ \\
\hline ISO 18756 & $\begin{array}{l}\text { Determination of fracture } \\
\text { toughness of monolithic ceramics } \\
\text { at room temp by surface crack in } \\
\text { flexure (SCF) method }\end{array}$ & 2003 & $\begin{array}{l}\text { C1421 Test Methods for the } \\
\text { Determination of Fracture } \\
\text { Toughness of Advanced } \\
\text { Ceramics }\end{array}$ & $\begin{array}{l}\text { G.D. Quinn (NIST) - } \\
\text { Convenor/US Expert }\end{array}$ \\
\hline ISO 20501 & $\begin{array}{l}\text { Weibull statistics for } \\
\text { strength data }\end{array}$ & 2003 & $\begin{array}{l}\text { C1239 Strength Data and } \\
\text { Estimating Weibull Distribution } \\
\text { Parameters for Advanced } \\
\text { Ceramics }\end{array}$ & $\begin{array}{l}\text { S.F. Duffy } \\
\text { (CSU, USA) - } \\
\text { Convenor/US Expert }\end{array}$ \\
\hline ISO 18754 & $\begin{array}{l}\text { Determination of density } \\
\text { and apparent porosity }\end{array}$ & 2003 & None at this time & R. Weber-US Expert \\
\hline ISO 20507 & Vocabulary & 2003 & $\begin{array}{l}\text { C1145 Terminology on } \\
\text { Advanced Ceramics }\end{array}$ & $\begin{array}{l}\text { J.A. Salem (NASA-GRC) - } \\
\text { US Expert }\end{array}$ \\
\hline ISO 18753 & $\begin{array}{l}\text { Determination of absolute } \\
\text { density of ceramic powders by } \\
\text { pycnometer }\end{array}$ & 2004 & None at this time & R. Weber-US Expert \\
\hline
\end{tabular}


Table II (cont'd)- ISO Standards developed with Committee C28 expertise and/or using C28 standards

\begin{tabular}{|c|c|c|c|c|}
\hline $\begin{array}{l}\text { ISO } \\
\text { TC206 } \\
\text { Number }\end{array}$ & $\begin{array}{l}\text { Title ISO TC206 Fine } \\
\text { ceramics (advanced } \\
\text { ceramics, advanced } \\
\text { technical ceramics)- }\end{array}$ & $\begin{array}{l}\text { Year } \\
\text { Approved }\end{array}$ & $\begin{array}{l}\text { Relevant ASTM C28 } \\
\text { Standard }\end{array}$ & $\begin{array}{l}\text { ASTM C } 28 \text { Project } \\
\text { Convenor/US Expe }\end{array}$ \\
\hline ISO 24369 & $\begin{array}{l}\text { Determination of content of } \\
\text { coarse particles in ceramic } \\
\text { powders by wet sieving method }\end{array}$ & 2005 & None at this time & $\begin{array}{l}\text { H. Giesche } \\
\text { (Alfred University)-US } \\
\text { Expert }\end{array}$ \\
\hline ISO24370 & $\begin{array}{l}\text { Test method for fracture } \\
\text { toughness of monolithic ceramics } \\
\text { at room temp. by chevron notched } \\
\text { beam (CNB) method }\end{array}$ & 2005 & $\begin{array}{l}\text { C1421 Test Methods for the } \\
\text { Determination of Fracture } \\
\text { Toughness of Advanced } \\
\text { Ceramics }\end{array}$ & $\begin{array}{l}\text { J.A. Salem (NASA- } \\
\text { GRC) - Convenor/US } \\
\text { Expert }\end{array}$ \\
\hline ISO 20505 & $\begin{array}{l}\text { Test method for interlaminar } \\
\text { shear behavior of continuous } \\
\text { fiber-reinforced composites at } \\
\text { ambient temperature }\end{array}$ & 2005 & $\begin{array}{l}\text { C1292 Test Method for Shear } \\
\text { Strength of Continuous Fiber- } \\
\text { Reinforced Advanced } \\
\text { Ceramics at Ambient } \\
\text { Temperatures }\end{array}$ & $\begin{array}{l}\text { E. Lara-Curzio (ORNL) } \\
\text {-Convenor/US Expert }\end{array}$ \\
\hline ISO 20505 & $\begin{array}{l}\text { Test method for in-plane shear } \\
\text { behavior of continuous fiber- } \\
\text { reinforced composites at ambient } \\
\text { temperature }\end{array}$ & 2005 & $\begin{array}{l}\text { C1292 Test Method for Shear } \\
\text { Strength of Continuous Fiber- } \\
\text { Reinforced Advanced } \\
\text { Ceramics at Ambient } \\
\text { Temperatures }\end{array}$ & $\begin{array}{l}\text { E. Lara-Curzio (ORNL) } \\
\text {-Convenor/US Expert }\end{array}$ \\
\hline ISO 18755 & $\begin{array}{l}\text { Determination of thermal } \\
\text { diffusivity of monolithic ceramics } \\
\text { by laser flash method }\end{array}$ & 2005 & None at this time & $\begin{array}{l}\text { D.P.H. Hasselman } \\
\text { (PSU) -US Expert }\end{array}$ \\
\hline ISO 20502 & $\begin{array}{l}\text { Determination of adhesion } \\
\text { of ceramic coatings by scratch } \\
\text { testing }\end{array}$ & 2005 & None at this time & $\begin{array}{l}\text { P. J. Blau (ORNL) -US } \\
\text { Expert }\end{array}$ \\
\hline ISO 22214 & $\begin{array}{l}\text { Test method for cyclic bending } \\
\text { fatigue of monolithic ceramics at } \\
\text { room temperature }\end{array}$ & 2006 & None at this time & $\begin{array}{l}\text { M. G. Jenkins (U } \\
\text { Detroit Mercy) -US } \\
\text { Expert }\end{array}$ \\
\hline ISO 22215 & $\begin{array}{l}\text { Test method for tensile creep of } \\
\text { monolithic ceramics }\end{array}$ & 2006 & $\begin{array}{l}\text { C1291 Test Method for } \\
\text { Elevated Temperature Tensile } \\
\text { Creep Strain, Creep Strain } \\
\text { Rate, and Creep Time-to- } \\
\text { Failure for Advanced } \\
\text { Monolithic Ceramics }\end{array}$ & $\begin{array}{l}\text { W. Luecke (NIST)-US } \\
\text { Expert }\end{array}$ \\
\hline ISO 20504 & $\begin{array}{l}\text { Test method for compressive } \\
\text { behavior of continuous } \\
\text { fiber-reinforced composites at } \\
\text { ambient temp. }\end{array}$ & 2006 & $\begin{array}{l}\text { C1358 Test Method for } \\
\text { Monotonic Compressive } \\
\text { Strength Testing of } \\
\text { Continuous Fiber-Reinforced } \\
\text { Advanced Ceramics with } \\
\text { Solid Rectangular Cross- } \\
\text { Section Specimens at Ambient } \\
\text { Temperatures }\end{array}$ & $\begin{array}{l}\text { M. G. Jenkins (U } \\
\text { Detroit Mercy) - } \\
\text { Convenor/US Expert }\end{array}$ \\
\hline ISO 24235 & $\begin{array}{l}\text { Determination of particle size } \\
\text { distribution of ceramic powders } \\
\text { by laser diffraction method }\end{array}$ & 2007 & $\begin{array}{l}\text { C1070-14 Test Method for } \\
\text { Determining Particle Size } \\
\text { Distribution of Alumina or } \\
\text { Quartz by Laser Light } \\
\text { Scattering }\end{array}$ & $\begin{array}{l}\text { H. Giesche } \\
\text { (Alfred University)-US } \\
\text { Expert }\end{array}$ \\
\hline
\end{tabular}

The LRP also included details of an operating plan that addressed development and maintenance of national and international standards for advanced ceramics as well as organization, leadership, membership, outreach and funding of Committee C28. The LRP is reviewed, updated, and circulated periodically [16]. As part of outreach, a summary and compilation of Committee C28 standards was created as a faux newsletter, called “Advanced Ceramic Sentinel.” This publication (see front page in Figure 3) was distributed on the web, at meetings and, for a time, on a CD as a hypertext-linked, interactive document. Similarly, a pictorial compilation of C28 standards was developed and distributed in poster form (see Figure 4). 
Table III - ASTM Special Technical Publications (STP) sponsored by Committee C28

\begin{tabular}{|l|l|l|l|}
\hline STP Number & Title & Year & Symposium Location \\
\hline STP 1201 & $\begin{array}{l}\text { Life Prediction Methodologies and Data for } \\
\text { Ceramic Materials }\end{array}$ & $\begin{array}{l}\text { Cocoa Beach, FL, Jan } \\
\text { 1993 w/ACerS }\end{array}$ \\
\hline STP 1309 & $\begin{array}{l}\text { Thermal and Mechanical Test Methods and } \\
\text { Behavior of Continuous-Fiber Ceramic } \\
\text { Composites }\end{array}$ & $\begin{array}{l}\text { Cocoa Beach, FL, Jan } \\
1996 \text { w/ACerS }\end{array}$ \\
\hline STP 1392 & $\begin{array}{l}\text { Mechanical, Thermal and Environmental } \\
\text { Testing and Performance of Ceramic } \\
\text { Composites and Components }\end{array}$ & 2000 & Seattle, WA, May 1999 \\
\hline STP 1409 & $\begin{array}{l}\text { Fracture Resistance Testing of Monolithic } \\
\text { and Composite Brittle Materials }\end{array}$ & Orlando, FL, Nov 2000 \\
\hline
\end{tabular}

While the number of new standards under the jurisdiction of Committee C28 grew rapidly during this period, the Committee also engaged in its first mandatory review of existing standards per ASTM requirements. Note that individual standards must be re-approved or revised every five years or they will be subject to mandatory withdrawal as active standards. This requirement assures that standards remain relevant and up-to-date. Figure 5 graphically represents the number of standards under jurisdiction of Committee C28 from its inception in 1986 to the present in 2016 as well as the number of standards requiring review in any given year.

Organization of the subcommittee structure of Committee C28 changed during this period as well with addition of two administrative subcommittees and the reorganization and renaming of several technical subcommittees. Part of this reorganization was the result of developing a long-range plan that included a refocus on user-specific standards (i.e., applications). Some areas that impacted applications included liaisons with Mil-Hdbk-17 on Composites, ASME Boiler and Pressure Vessel Code and Gas Research Institute. This reorganization is illustrated as follows.

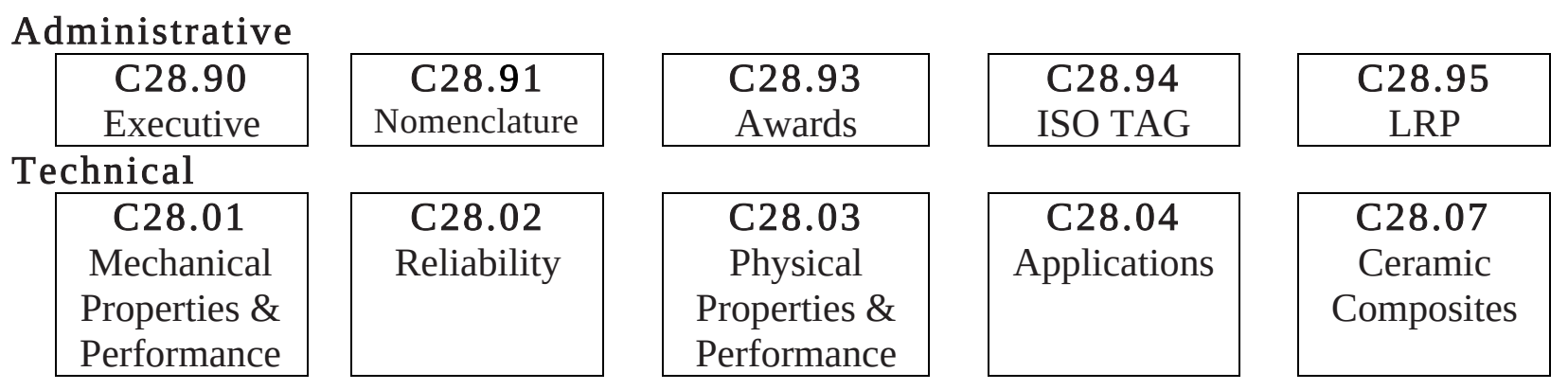

Another change that was implemented for a short time was the semi-annual meeting location and schedule. Since its inception, Committee C28 had sought to develop a close relationship with ACerS by scheduling one of its twice-a-year meetings in conjunction with one of the major meetings of ACerS. Up until about 1999, Committee C28 had been one of these meetings in January at the "Cocoa Beach" conference of ACerS in and then the other meeting was held wherever ASTM was meeting in May/June in order to interact with fellow ASTM committees such as E08 on Fatigue and Fracture or D30 on Composites. Starting in 2000, Committee C28 changed its meeting schedule such that its April/May meeting was in conjunction with the ACerS annual meeting and its November meeting was during an ASTM committee week. Part of the motivation for this change was to interact with a broader ceramics community. In addition, Committee C28 organized sessions on standards at the ACerS annual meeting in order to educated and reach out the broader ceramics community.

A summary of standards developed and published in the transition years is contained in Table IV. 


\section{Advanced Ceramic Sentinel}

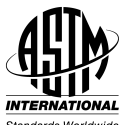

An Information Summary for

ASTM Committee C28 on Advanced Ceramics

July 2016 - Celebrating 30 years of Excellence

\section{Scope of Committee C28}

The promotion of knowledge, stimulation of research and development of standards (classifications, specifications, nomenclature, test methods, guides, and practices) relating to processing, properties, characterization, and performance of advanced ceramic materials.

This committee works in concert with other technical committees (e.g., D30 "Composite Materials," E07 "Non Destructive Testing," E08 "Fatigue and Fracture," E28 "Mechanical Testing," F04 "Medical and Surgical Materials and Devices", and G02 "Wear and Erosion") and other national and international organizations having mutual or related interests.

\section{What Committee C28 Does}

Committee C28 develops and maintains standards for monolithic and composite advanced ceramics. An advanced ceramic is a highly-engineered, highperformance predominately non-metallic, inorganic, ceramic material having specific functional attributes. The C28 standards cover methods for testing bulk and constituent (powders, fibres, etc.) properties, thermal and physical properties, strengths and strength distributions, and performance under varying environmental, thermal, and mechanical conditions. The scope of application of the methods ranges from quality control through design data generation.

The Committee's primary objective is the development of technically rigorous standards which are accessible to the general industrial laboratory and consequently are widely accepted and used in the design, production, and utilization of advanced ceramics.

While the committee's roots are in energy-related industries and programs, C28 supports the needs of automotive, aerospace, electronic, medical and other industries requiring advanced ceramics. Some specific applications include nano-ceramics, bio-ceramics, coatings, electronics, sensors/actuators, porous substrates and fuel cells. C28 actively pursues standards development to support these emerging applications.

Committee C28 coordinates its work with other organizations with mutual interests in advanced ceramics. The membership represents an international group of people interested in furthering advanced ceramic technology.

In addition to standards development, C28 sponsors symposia providing a forum for the timely transfer of technical information relevant to the design, analysis, processing, fabrication, and characterization of monolithic and composite advanced ceramics. Special workshops and technical presentations are often held to identify specific industrial needs and support the technical development of new standards.

The Committee meets twice a year in with an on-site meeting and a Web-teleconference. The Committee is self-regulated by committee-approved by-laws under the auspices of ASTM International

\begin{tabular}{|c|c|c|c|c|}
\hline \multicolumn{5}{|c|}{$\begin{array}{lc} & \text { COMMITTEE C28 - ADVANCED CERAMICS } \\
\text { Chair: } & \text { 2016-18 Officers and Committee Structure } \\
\text { Vice Chair: } & \text { Tony Thornton, Micromeritics } \\
\text { Recording Secretary: } & \text { Michael Jenkins, Bothell Eng \& Science Technologies } \\
\text { Membership Secretary: Jonathan Salem, NASA Glenn Research Center }\end{array}$} \\
\hline $\begin{array}{c}\text { C28.90 } \\
\text { Executive } \\
\end{array}$ & $\begin{array}{c}\text { C28.92 } \\
\text { Education / Outreach }\end{array}$ & $\begin{array}{r}\text { C28.93 } \\
\text { Awards }\end{array}$ & $\begin{array}{c}\text { C28.95 } \\
\text { Long Range Planning } \\
\end{array}$ & \\
\hline \begin{tabular}{|c|} 
C28.01 \\
Mechanical \\
Properties and \\
Reliability
\end{tabular} & \begin{tabular}{|c|} 
C28.03 \\
Physical Properties \\
and NDE
\end{tabular} & \begin{tabular}{c|} 
C28.04 \\
Ceramic \\
Applications
\end{tabular} & $\begin{array}{c}\text { C28.07 } \\
\text { Ceramic Matrix } \\
\text { Composites }\end{array}$ & $\begin{array}{c}\text { C28.91 } \\
\text { Nomenclature and } \\
\text { Editorial }\end{array}$ \\
\hline
\end{tabular}

Figure 3 - Front page of Advanced Ceramic Sentinel used for outreach 


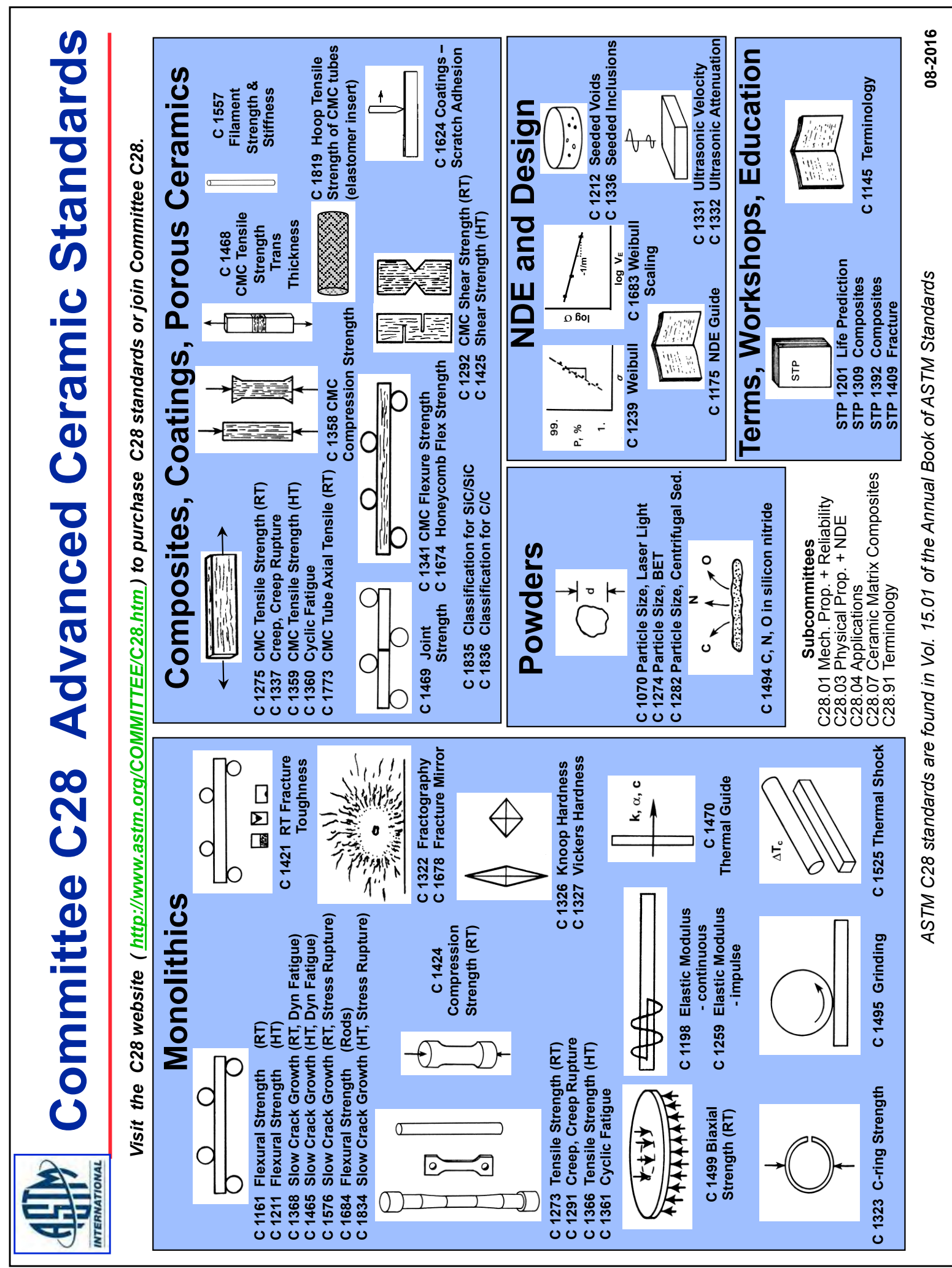

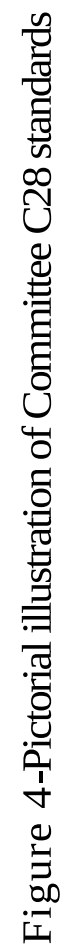




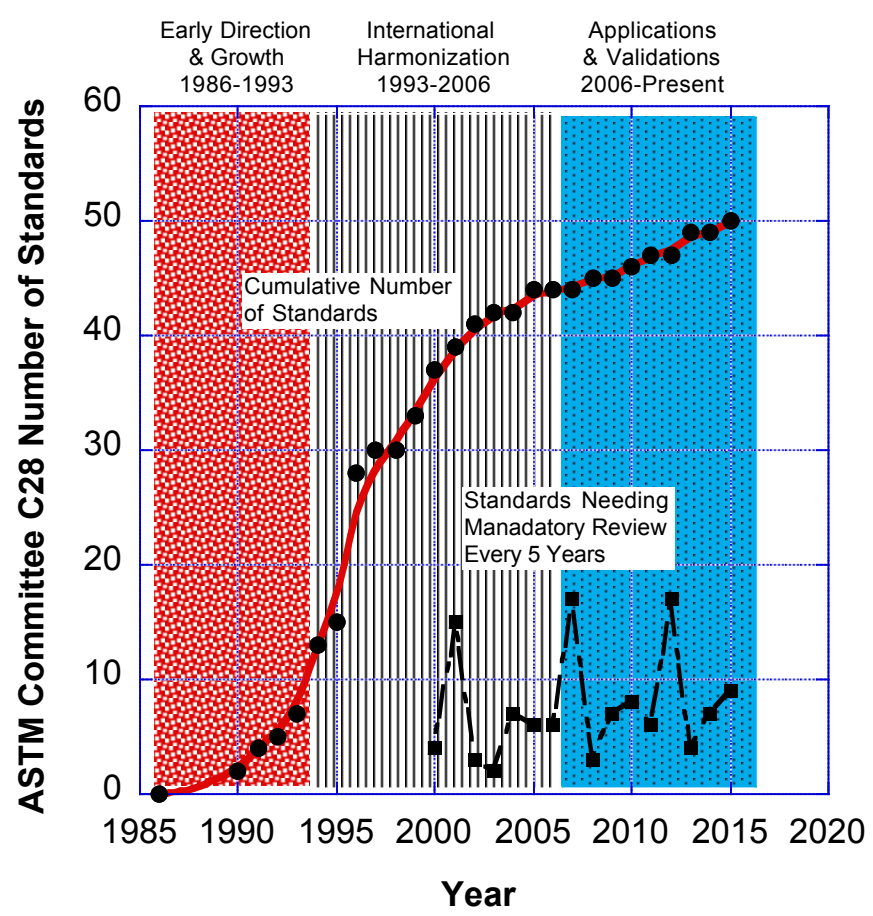

Figure 5 - Cumulative number of Committee C28 standards and number of standards needing mandatory review in any given year

\section{Committee C28: Present Years - Applications and Validations (2006-Present)}

Reflecting on the long-range plan and the increasing time-commitment to the duality of development/upkeep of ASTM standards and the development/upkeep of ISO TC206 standards, Committee C28 made a decision to reassess its role in standards development. That reassessment occurred about the time more emphasis was being placed on applications such as ionized glass for touch screens, electrolytes for solid oxide fuel cells (SOFCs), windows in aerospace applications/transparent armor, porous ceramics for filters, traps and substrates, and joining materials for ceramic joints. In addition, a new initiative from US-DOE called Next Generation Nuclear Power (NGNP) was calling for new standards to assess the mechanical, physical, and thermal behavior of CFCC materials in unique shapes such as tubes [29].

Committee C28 was once again reorganized to reflect changes in direction. A major change was the decision to withdraw official participation in ISO TC206. This decision would significantly reduce time and financial commitments as well as eliminate the need for Subcommittee C28.94. In addition, it was decided to focus more effort on education and outreach in order the "get the word out" on C28 standards and their applications. This decision lead to the creation of Subcommittee C28.92 Education and Outreach. The new organizational structure is illustrated as follows.

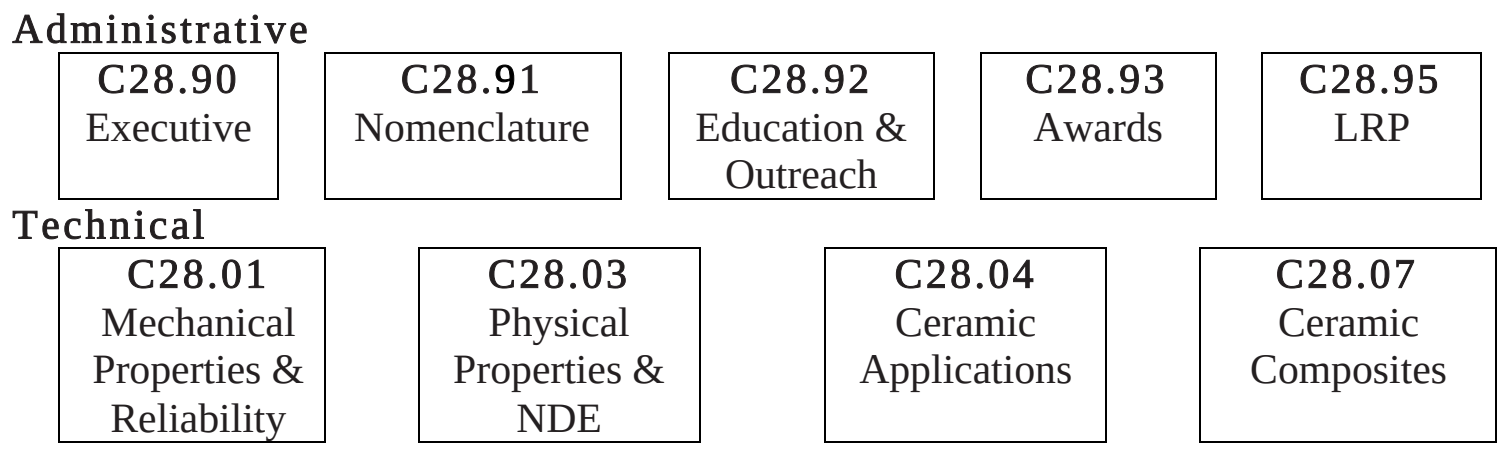


Table IV - Committee C28 standards developed and published in its Transition Years (1993-2006)

\begin{tabular}{|c|c|c|c|}
\hline $\begin{array}{c}\text { Number } \\
\text { (current } \\
\text { version year) }\end{array}$ & Title & $\begin{array}{c}\text { Year } \\
\text { Approved } \\
\text { \& First } \\
\text { Published }\end{array}$ & $\begin{array}{l}\text { Current } \\
\text { Responsible } \\
\text { Subcommittee }\end{array}$ \\
\hline C1259 (2015) & $\begin{array}{l}\text { Test Method for Dynamic Young's Modulus, Shear Modulus, } \\
\text { and Poisson's Ratio for Advanced Ceramics by Impulse } \\
\text { Excitation of Vibration }\end{array}$ & 1994 & C28.01 \\
\hline C1273 (2015) & $\begin{array}{l}\text { Test Method for Tensile Strength of Monolithic Advanced } \\
\text { Ceramics at Ambient Temperatures }\end{array}$ & 1994 & C28.01 \\
\hline C1274 (2012) & $\begin{array}{l}\text { Test Method for Advanced Ceramic Specific Surface Area by } \\
\text { Physical Adsorption }\end{array}$ & 1994 & C28.03 \\
\hline C1275 (2015) & $\begin{array}{l}\text { Test Method for Monotonic Tensile Behavior of Continuous } \\
\text { Fiber-Reinforced Advanced Ceramics with Solid Rectangular } \\
\text { Cross-Section at Ambient Temperatures }\end{array}$ & 1994 & C28.07 \\
\hline $\begin{array}{l}\text { C1282 (2008) } \\
\text { withdrawn } 2014\end{array}$ & $\begin{array}{l}\text { Test Method for Determining the Particle Size Distribution of } \\
\text { Advanced Ceramics by Centrifugal Photo-sedimentation }\end{array}$ & 1995 & C28.02 \\
\hline $\begin{array}{l}\text { C1286 (1994) } \\
\text { withdrawn } 2001\end{array}$ & Classification for Advanced Ceramics & 1994 & C28.91 \\
\hline C1291 (2010) & $\begin{array}{l}\text { Test Method for Elevated Temperature Tensile Creep Strain, } \\
\text { Creep Strain Rate, and Creep Time-to-Failure for Advanced } \\
\text { Monolithic Ceramics }\end{array}$ & 1995 & C28.01 \\
\hline C1292 (2010) & $\begin{array}{l}\text { Test Method for Shear Strength of Continuous Fiber-Reinforced } \\
\text { Advanced Ceramics at Ambient Temperatures }\end{array}$ & 1995 & C28.07 \\
\hline C1322 (2015) & $\begin{array}{l}\text { Practice for Fractography and Characterization of Fracture } \\
\text { Origins in Advanced Ceramics }\end{array}$ & 1996 & C28.01 \\
\hline C1323 (2010) & $\begin{array}{l}\text { Test Method for Ultimate Strength of Advanced Ceramics with } \\
\text { Diametrally Compressed C-Ring Specimens at Ambient } \\
\text { Temperature }\end{array}$ & 1996 & C28.04 \\
\hline C1326 (2013) & $\begin{array}{l}\text { Test Method for Knoop Indentation Hardness of Advanced } \\
\text { Ceramics }\end{array}$ & 1996 & $\mathrm{C} 28.01$ \\
\hline C1327 (2015) & $\begin{array}{l}\text { Test Method for Vickers Indentation Hardness of Advanced } \\
\text { Ceramics }\end{array}$ & 1996 & C28.01 \\
\hline C1331 (2012) & $\begin{array}{l}\text { Practice for Measuring Ultrasonic Velocity in Advanced } \\
\text { Ceramics with the Broadband Pulse-Echo Cross-Correlation } \\
\text { Method }\end{array}$ & 1996 & $\mathrm{C} 28.03$ \\
\hline C1332 (2013) & $\begin{array}{l}\text { Test Method for Measurement of Ultrasonic Attenuation } \\
\text { Coefficients of Advanced Ceramics by the Pulse-Echo Contact } \\
\text { Technique }\end{array}$ & 1996 & C28.03 \\
\hline C1336 (2014) & $\begin{array}{l}\text { Practice for Fabricating Non-Oxide Ceramic Reference } \\
\text { Specimens Containing Seeded Inclusions }\end{array}$ & 1996 & C28.03 \\
\hline C1337 (2015) & $\begin{array}{l}\text { Test Method for Creep and Creep Rupture of Continuous Fiber- } \\
\text { Reinforced Ceramic Composites under Tensile Loading at } \\
\text { Elevated Temperature }\end{array}$ & 1996 & C28.07 \\
\hline C1341 (2013) & $\begin{array}{l}\text { Test Method for Flexural Properties of Continuous Fiber- } \\
\text { Reinforced Advanced Ceramic Composites }\end{array}$ & 1996 & C28.07 \\
\hline C1358 (2013) & $\begin{array}{l}\text { Test Method for Monotonic Compressive Strength Testing of } \\
\text { Continuous Fiber- Reinforced Advanced Ceramics with Solid } \\
\text { Rectangular Cross-Section Specimens at Ambient Temperatures }\end{array}$ & 1996 & $\mathrm{C} 28.07$ \\
\hline C1359 (2013) & $\begin{array}{l}\text { Test Method for Monotonic Tensile Strength Testing of } \\
\text { Continuous Fiber-Reinforced Advanced Ceramics with Solid } \\
\text { Rectangular Cross-Section Specimens at Elevated Temperatures }\end{array}$ & 1996 & C28.07 \\
\hline C1360 (2013) & $\begin{array}{l}\text { Practice for Constant-Amplitude, Axial, Tension-Tension Cyclic } \\
\text { Fatigue of Continuous Fiber-Reinforced Advanced Ceramics at } \\
\text { Ambient Temperatures }\end{array}$ & 1996 & C28.07 \\
\hline C1361 (2015) & $\begin{array}{l}\text { Practice for Constant-Amplitude, Axial, Tension-Tension Cyclic } \\
\text { Fatigue of Advanced Ceramics at Ambient Temperatures }\end{array}$ & 1996 & C28.01 \\
\hline C1366 (2013) & $\begin{array}{l}\text { Test Method for Tensile Strength of Monolithic Advanced } \\
\text { Ceramics at Elevated Temperatures }\end{array}$ & 1997 & C28.01 \\
\hline C1368 (2010) & $\begin{array}{l}\text { Test Method for Determination of Slow Crack Growth } \\
\text { Parameters of Advanced Ceramics by Constant Stress-Rate } \\
\text { Flexural Testing at Ambient Temperature }\end{array}$ & 1997 & C28.01 \\
\hline
\end{tabular}


Table IV (cont'd)- Committee C28 standards developed and published in its Transition Years (1993-2006)

\begin{tabular}{|c|c|c|c|}
\hline $\begin{array}{l}\text { Number } \\
\text { (current } \\
\text { version year) }\end{array}$ & Title & $\begin{array}{c}\text { Year } \\
\text { Approved } \\
\text { \& First } \\
\text { Published } \\
\end{array}$ & $\begin{array}{c}\text { Current } \\
\text { Responsible } \\
\text { Subcommittee }\end{array}$ \\
\hline C1421 (2015) & $\begin{array}{l}\text { Test Methods for the Determination of Fracture Toughness of } \\
\text { Advanced Ceramics }\end{array}$ & 1999 & C28.01 \\
\hline C1424 (2015) & $\begin{array}{l}\text { Test Method for Compressive Strength of Monolithic Advanced } \\
\text { Ceramics at Ambient Temperatures }\end{array}$ & 1999 & C28.01 \\
\hline C1425 (2013) & $\begin{array}{l}\text { Test Method for Interlaminar Shear Strength of 1-D and 2-D } \\
\text { CFCCs at Elevated Temperatures }\end{array}$ & 1999 & C28.07 \\
\hline C1465 (2013) & $\begin{array}{l}\text { Test Method for Determination of Slow Crack Growth } \\
\text { Parameters of Advanced Ceramics by Constant Stress-Rate } \\
\text { Flexural Testing at Elevated Temperature }\end{array}$ & 2000 & C28.01 \\
\hline C1468 (2013) & $\begin{array}{l}\text { Test Method for Transthickness Tensile Strength of Continuous } \\
\text { Fiber- Reinforced Advanced Ceramics at Ambient Temperatures }\end{array}$ & 2000 & C28.07 \\
\hline C1469 (2010) & $\begin{array}{l}\text { Test Method for Shear Strength of Joints of Advanced Ceramics } \\
\text { at Ambient Temperature }\end{array}$ & 2000 & C28.07 \\
\hline C1470 (2013) & Guide for Testing the Thermal Properties of Advanced Ceramics & 2000 & C28.03 \\
\hline C1494 (2013) & $\begin{array}{l}\text { Test Method for Determination of Mass Fraction of Carbon, } \\
\text { Nitrogen, and Oxygen in Silicon Nitride Powder }\end{array}$ & 2001 & C28.03 \\
\hline C1495 (2012) & $\begin{array}{l}\text { Test Method for Effect of Surface Grinding on Flexure Strength } \\
\text { of Advanced Ceramics }\end{array}$ & 2001 & C28.01 \\
\hline C1499 (2013) & $\begin{array}{l}\text { Test Method for Monotonic Equibiaxial Flexural Strength } \\
\text { Testing of Advanced Ceramics at Ambient Temperature }\end{array}$ & 2002 & C28.01 \\
\hline C1525 (2012) & $\begin{array}{l}\text { Test Method for Determination of Thermal Shock Resistance for } \\
\text { Advanced Ceramics by Water Quenching }\end{array}$ & 2002 & C28.01 \\
\hline C1557 (2014) & Test Method for Tensile Strength and Young's Modulus Fibers & 2003 & C28.07 \\
\hline C1576 (2013) & $\begin{array}{l}\text { Test Method for Determination of Slow Crack Growth } \\
\text { Parameters of Advanced Ceramics by Constant Stress Flexural } \\
\text { Testing (Stress Rupture) at Ambient Temperature }\end{array}$ & 2005 & C28.01 \\
\hline C1624 (2015) & $\begin{array}{l}\text { Test Method for Adhesion Strength and Mechanical Failure } \\
\text { Modes of Ceramic Coatings by Quantitative Single Point Scratch } \\
\text { Testing }\end{array}$ & 2005 & C28.04 \\
\hline
\end{tabular}

In 2006, Committee C28 once again changed its meeting schedule back to the original one of meeting in January at the "Cocoa Beach" conference of ACerS and then wherever ASTM was meeting in May/June in order to interact with fellow ASTM committees such as E08 on Fatigue and Fracture or D30 on Composites. The change was made based on the realization that the January time, the Cocoa Beach location, and the smaller ACerS conference provided better interaction with those who mattered in the ceramics community than the constantly shifting and much larger annual ACerS annual meeting. However, Committee C28 soon decided that for economy of both time and finances, a teleconference meeting might be better investment for its midyear meeting. As a result, the current, and relatively successful twice-a-year meeting schedule for Committee C28 is as follows: Late January in conjunction with ACerS International Conference on Advanced Ceramics and Composites (ICACC) in Daytona Beach, Florida and in mid-July as a WebEx ${ }^{\mathrm{TM}}$ teleconference.

Reflecting its emphasis on education and outreach, Committee C28 has presented a poster on standards for ceramics at the Poster Session of the ICACC for the last half decade. Recently, the Committee has created a LinkedIn ${ }^{\mathrm{TM}}$ presence. Other initiatives include regular articles in ASTM's Standardization News and ACerS’s Ceramic Technology burst e-mail and Ceramic Bulletin. 
It should be noted that one of the hallmarks of ASTM standards that contributes to their technical rigor and high quality is the Precision and Bias (P\&B) statement. The $\mathrm{P} \& \mathrm{~B}$ statement is required by ASTM in all test methods and provides the user with insight on the repeatability (precision) of the procedures and their accuracy (i.e., bias) to some known reference material. Typically round robin test programmes per Practice E691 [30] are used to produce inter- and intralaboratory repeatability values. Over the years members of Committee C28 have been instrumental in organizing, participating, interpreting and applying round robins for validating not just ASTM C28 standards but ISO and other SWO standards as well. Table V provides a brief summary of many of these round robins.

The current subcommittee structure and their functions are summarized as follows.

C28.90 Executive This subcommittee manages administrative matters of main Committee C28 through its membership comprised of the committee and subcommittee officers of C28.

C28.91 Nomenclature and Editorial This subcommittee compiles nomenclature and terminology used in the various standards of Committee C28.

C28.92 Education and Outreach This subcommittee develops and supports efforts for education and outreach for the C28 committee.

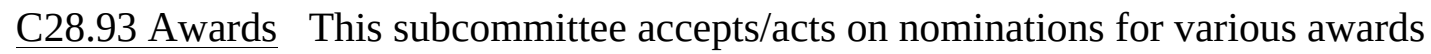

C28.95 Long Range Planning This subcommittee proposes, facilitates and promotes long range planning activities consistent with the mission.

C28.01 Mechanical Properties \& Reliability This subcommittee develops standards for mechanical properties and reliability (short term and long term) of monolithic advanced ceramics in a number of areas including flexural strength, tensile strength, compressive strength, cyclic fatigue, creep and creep rupture, hardness, and fracture toughness.

C28.03 Physical Properties \& NDE This subcommittee develops standards for physical, chemical, micro-structural, and non-destructive characterization of powder and bulk advanced ceramics.

C28.04 Applications This subcommittee develops standards (including guides, specifications, practices, test methods) for various engineering applications of advanced ceramics, such as nanoceramics, coatings, electrodes, porous ceramics, fuel cells, armor, sensors/actuators, and thermal systems.

C28.07 Ceramic Matrix Composites This subcommittee develops standards for determination of the thermo-mechanical properties and performance of ceramic matrix composites including tension, compression, shear, flexure, cyclic fatigue, creep/creep rupture, ceramic fibers, interfacial properties, thermo-mechanical fatigue, environmental effects, and structural/component testing.

A summary of Committee C28 standards published since 2006 is shown in Table VI. 
Table V-Partial list of many of the round robins that have contributed to standards for ceramics

\begin{tabular}{|c|c|}
\hline Sponsor: ASTM-International and Focus & Standard P\&B Benefit \\
\hline Young’s Modulus and Poisson’s Ratio & ASTM C1259 \\
\hline Flexural Strength of Ceramic Matrix Composites & ASTM C1341 \\
\hline Trans-Laminar Tensile Strength of Ceramic Composites & ASTM C1468 \\
\hline Tensile Creep of Silicon Nitride & ASTM C1291 \\
\hline Sponsor: International Energy Agreement (IEA) & \\
\hline Flexural Strength Testing of Ceramics & ASTM C1161 \\
\hline Effect of Machining Conditions on the Strength of Silicon Nitride & ASTM C1495 \\
\hline Tensile Strength Testing of Ceramics & ASTM C1273 \\
\hline $\begin{array}{l}\text { Sponsor: Versailles Project on Advanced Materials and } \\
\text { Standards (VAMAS) }\end{array}$ & \\
\hline Fracture Toughness by the Surface Crack Method & ASTM C1421 \\
\hline Fracture Toughness of Silicon Nitride at High Temperature & JIS 1617 \\
\hline Fractography of Advanced Ceramics & ASTM C1322 \\
\hline - $\quad$ Fracture Toughness of Advanced Ceramics at Room Temperature & ASTM C1421 \\
\hline Fracture Toughness of Ceramic Matrix Composite & None at this time \\
\hline $\begin{array}{ll} & \text { Fracture Toughness of Ceramics using the SEVNB Method }\end{array}$ & ISO 23146 \\
\hline - $\quad$ Inert Strength of Ceramics & None at this time \\
\hline Sponsor: US DOE CFCC Programme & \\
\hline - Tensile, Flexure and Shear Behavior of a Ceramic Matrix Co & $\begin{array}{l}\text { ASTM C1275, C1292, } \\
\text { C1341, C1468 }\end{array}$ \\
\hline
\end{tabular}

\section{TANGIBLE BENEFITS OF STANDARDS}

Although many examples of tangible benefits of ASTM C28 standards could be cited only a few are given here in the interests of brevity.

1) F2393 Standard Specification for High-Purity Dense Magnesia Partially Stabilized Zirconia (Mg-PSZ) for Surgical Implant Applications [31]

ASTM Committee F04 on Surgical and Medical Devices and the U.S. Food and Drug Administration used generic standards from Committee C28 for their standard specification, F2393. Figure 5 shows an example of a zirconia implant. Some specifics are as follows:

- $\quad$ "The average room temperature flexural strength shall be $600 \mathrm{MPa}$ (87 $000 \mathrm{psi}$ ) or greater by 4 point bend testing in accordance with Test Method C1161, test configuration B. A minimum of 10 samples are to be tested."

- $\quad$ "If Weibull modulus is determined, test results shall be evaluated in accordance with Practice C1239. The minimum number of test specimens shall be 30 and the minimum acceptable uncensored, unbiased Weibull modulus shall be 10.”

- $\quad$ "The minimum room temperature elastic modulus shall be $180 \mathrm{GPa}$ (26 $200 \mathrm{ksi}$ ) in accordance with Test Method C1198. A rectangular specimen with dimensions of 60 by 10 by $3 \mathrm{~mm}$ is recommended. An acceptable alternative test method for elastic modulus is Test Method C1259."

- The minimum Vickers hardness value shall be $1000 \mathrm{HV}$ in accordance with Test Method C1327. The load shall be $9.8 \mathrm{~N}(1 \mathrm{~kg})$ and the dwell time shall be $15 \mathrm{~s}$. 
Table VI -Committee C28 standards developed and published in its Present Years (2006-Present)

\begin{tabular}{|c|c|c|c|}
\hline $\begin{array}{l}\text { Number (current } \\
\text { version year) }\end{array}$ & Title & $\begin{array}{l}\text { Year Approved \& } \\
\text { First Published }\end{array}$ & $\begin{array}{l}\text { Responsible } \\
\text { Subcommittee }\end{array}$ \\
\hline C1674 (2011) & $\begin{array}{l}\text { Standard Test Method for Flexural Strength of } \\
\text { Advanced Ceramics with Engineered Porosity } \\
\text { (Honeycomb Cellular Channels) at Ambient } \\
\text { Temperatures }\end{array}$ & 2011 & C28.05 \\
\hline C1678 (2010) & $\begin{array}{l}\text { Standard Practice for Fractographic Analysis of } \\
\text { Fracture Mirror Sizes in Ceramics and Glasses }\end{array}$ & 2010 & C28.01 \\
\hline C1683 (2015) & $\begin{array}{l}\text { Standard Practice for Size Scaling of Tensile } \\
\text { Strengths Using Weibull Statistics for Advanced } \\
\text { Ceramics }\end{array}$ & 2008 & C28.01 \\
\hline C1684 (2013) & $\begin{array}{l}\text { Standard Test Method for Flexural Strength of } \\
\text { Advanced Ceramics at Ambient Temperature - } \\
\text { Cylindrical Rods }\end{array}$ & 2013 & C28.01 \\
\hline C1773 (2013) & $\begin{array}{l}\text { Standard Test Method for Monotonic Axial } \\
\text { Tensile Behavior of Continuous Fiber-Reinforced } \\
\text { Advanced Ceramic Tubular Test Specimens at } \\
\text { Ambient Temperature }\end{array}$ & 2013 & C28.07 \\
\hline C1783 (2015) & $\begin{array}{l}\text { Standard Guide for }{ }^{2} \text { Development of } \\
\text { Specifications for Fiber Reinforced Silicon } \\
\text { Carbide-Silicon Carbide Composite Structures for } \\
\text { Nuclear Applications }\end{array}$ & 2015 & C28.07 \\
\hline C1793 (2015) & 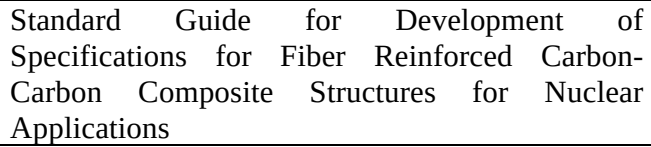 & 2015 & C28.07 \\
\hline C1819 (2015) & $\begin{array}{l}\text { Standard Test Method for Hoop Tensile Strength } \\
\text { of Continuous Fiber-Reinforced Advanced } \\
\text { Ceramic Composite Tubular Test Specimens at } \\
\text { Ambient Temperature Using Elastomeric Inserts }\end{array}$ & 2015 & C28.07 \\
\hline C1834 (2016) & $\begin{array}{l}\text { Standard Test Method for Determination of Slow } \\
\text { Crack Growth Parameters of Advanced Ceramics } \\
\text { by Constant Stress Flexural Testing (Stress } \\
\text { Rupture) at Elevated Temperatures }\end{array}$ & 2016 & C28.01 \\
\hline C1835 (2016) & $\begin{array}{l}\begin{array}{l}\text { Standard Classification for Fiber } \\
\text { Silicon Reinforced } \\
\text { Composite Structures }\end{array} \\
\text { Carbide-Silicon } \\
\text { Carbide }\end{array}$ & 2016 & C28.07 \\
\hline C1836 (2016) & $\begin{array}{l}\text { Standard Classification for Fiber Reinforced } \\
\text { Carbon-Carbon Composite Structures }\end{array}$ & 2016 & C28.07 \\
\hline
\end{tabular}

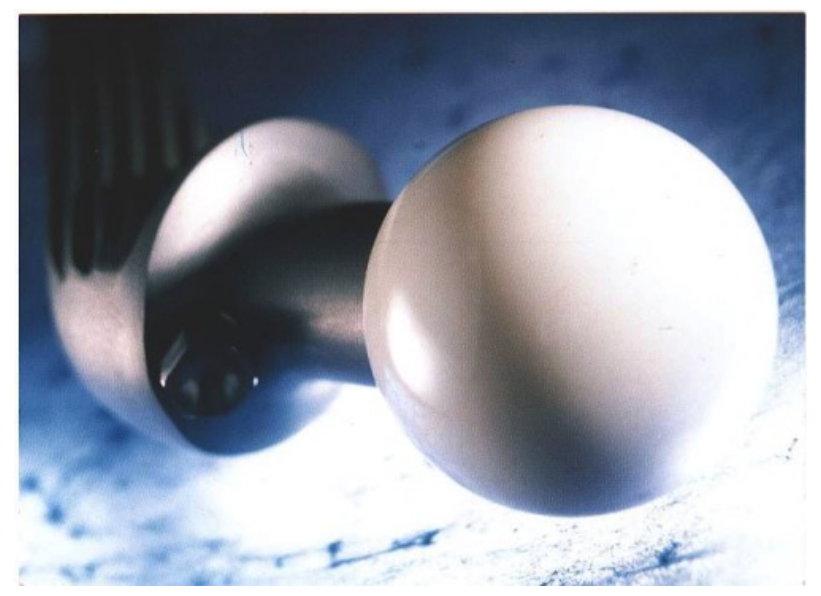

Figure 5-Example of Mg-PSZ surgical implant 


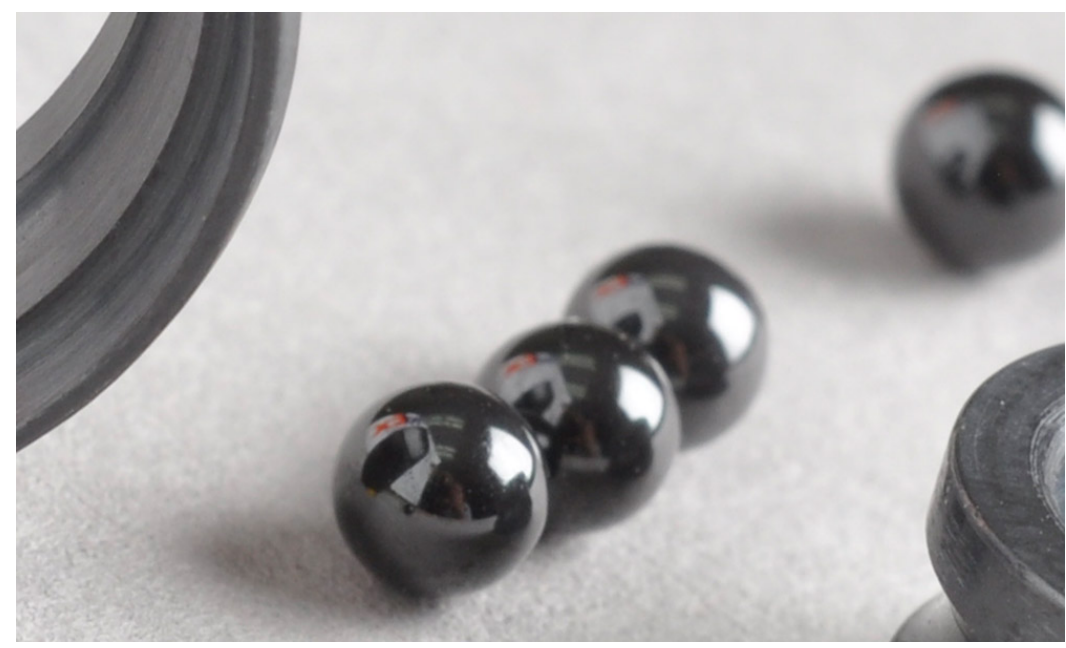

Figure 6-Examples of silicon nitride rolling elements http://www.ortechceramics.com/product-category/ceramic-bearings/

\section{2) F2094/F2094M Standard Specification for Silicon Nitride Bearing Balls [32]}

ASTM Committee F34 on Rolling Element Bearings used generic standards from Committee C28 for their standard specification, F2094. Figure 6 shows examples of silicon nitride ball bearings. Some specifics are as follows:

- "Either 3-point or 4-point test methods may be used for flexural strength, which should be measured in accordance with Test Method C1161 (size B)...”

- "Fracture resistance shall be measured by either ...... (see Annex A1) or by a standard fracture toughness test method." (C1421)

\section{3) Transparent Armor Ceramics as Spacecraft Windows}

Standards from Committee C28 allowed comparisons among authors and helped to interpret data. Figures 7 and 8 illustrate results from using these standards for this application. In particular:

- $\quad$ Standardized fracture toughness tests using Test Method C1421 ensured correct comparisons of different authors' results [33].

- $\quad$ Standard-sized circular disks could be used to determine Poisson's ratio and Young's modulus via Test Method C1259 and biaxial strength via Test Method C1499 as well as the slow crack growth parameters, $\mathrm{n}$ and A, via Test Method C1368. This allowed efficient understanding of the behavior of the material [33].

4) Standard Reference Materials

Standard Reference Materials (SRMs) certified by NIST are available for users to verify test procedures including user techniques and test apparati. In particular:

- $\quad$ SRM 2100 was developed to improve fracture toughness testing of ceramics. It may be used with conventional testing machines and flexure (bend bar) test configurations. The SRM is a set of five hot-isostatically pressed silicon nitride test specimens. The fracture toughness is certified by billet of the SRM material. For example, Billet $C$ is certified to have a mean $\mathrm{K}_{\mathrm{Ic}}=4.572 \mathrm{MPa} \bullet \mathrm{m}^{1 / 2}$ and uncertainty of $0.228 \mathrm{MPa} \cdot \mathrm{m}^{1 / 2}$ (5\% of mean) for a single test specimen and $0.106 \mathrm{MPa} \cdot \mathrm{m}^{1 / 2}(2.3 \%$ of mean) for all five test specimens. (Test Method C1421) [34]. 


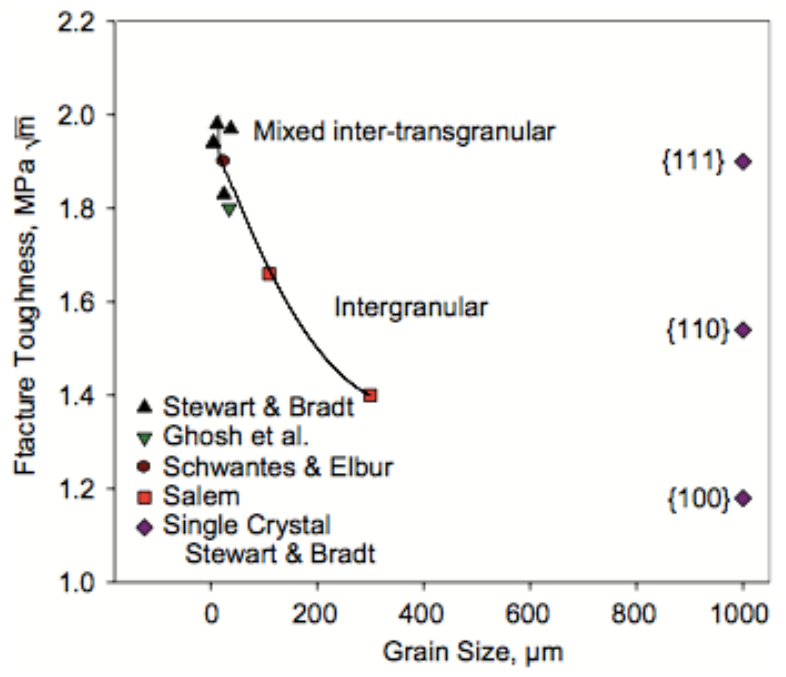

Figure 7-Fracture toughness of window material for different crystallographic planes [30]

- $\quad$ SRM 2830 was developed to improve Knoop hardness testing of ceramics. It may be used with conventional hardness testing machines that make indentations that are measured with an optical microscope. The SRM is prepared from a silicon nitride ceramic bearing ball in which five indentations have been made at a load of $19.6 \mathrm{~N}$ (2 kgf). Each SRM is individually certified for the size of each of the 5 indentations with average diagonal length $(\approx 142.0 \mu \mathrm{m})$, and average hardness HK2. The HK2 is nominally 13.86 GPa or 1,414 HK2. (Test Method C1326) [35].

- $\quad$ SRM 2831 was developed to improve Vickers hardness testing of ceramics and hardmetals. It may be used with conventional hardness testing machines that make indentations that are measured with an optical microscope. The SRM is a hot-isostatically pressed tungsten carbide with $12 \%$ cobalt disk which has five indentations made at a load of $9.8 \mathrm{~N}$ (1 kgf). Each SRM is individually certified for the size of each of the 5 indentations, the average diagonal length $(\approx 35.0 \mu \mathrm{m})$, and the average hardness HV1. The HV1 is nominally $15 \mathrm{GPa}$ which is in middle of the hardness range for most ceramics and cutting tool carbides (Test Method C1327) [36].

\section{CONCLUSIONS}

Market demand for advanced ceramics and ceramic matrix composites is expected to continue to grow as these materials improve in consistency and reliability while simultaneously reducing cost. Standardized test methods are expected to accelerate use of these materials as they become available and are used nationally and internationally. ASTM Committee C28 on Advanced Ceramics has produced, as of this writing, fifty high-quality, technically-rigorous consensus standards for processing, characterization, design, and evaluation of this class of materials. These activities have accelerated in recent years and many more standards are expected to be completed in the near future.

\section{ACKNOWLEDGEMENT}

This work was conducted with partial funding from the U.S. Department of Energy under the technical direction of Dr. Yutai Katoh at Oak Ridge National Laboratory, Oak Ridge, TN. 


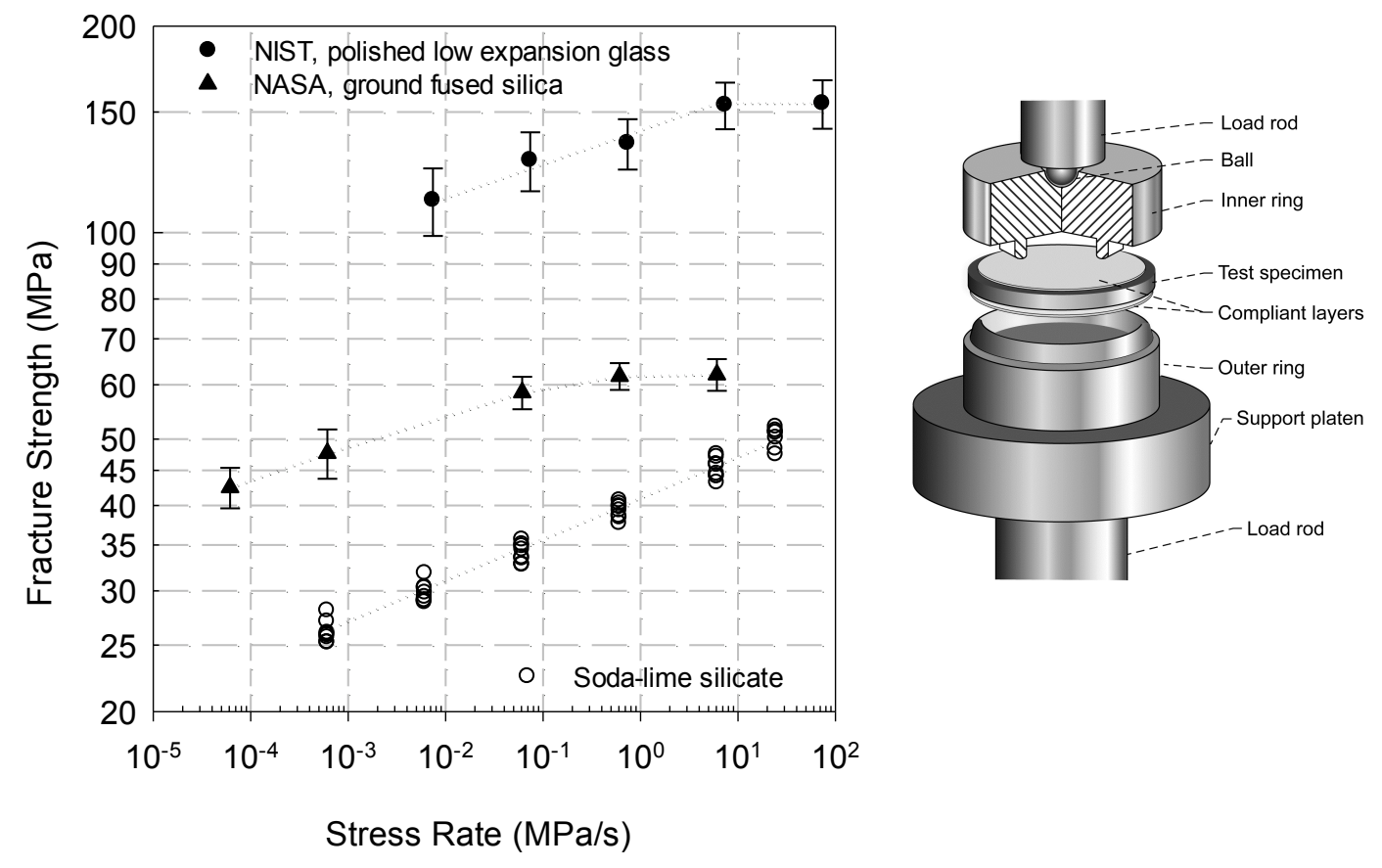

Figure 8 - Comparison of biaxial flexural strength for two window materials [30]

\section{REFERENCES}

1. ASTM C1145 "Standard Terminology on Advanced Ceramics," in Annual Book of ASTM Standards, Vol. 15.01, ASTM International, West Conshohocken, Penn. (2016)

2. Glenny, E., "Ceramics and the Gas Turbine,” in Special Ceramics 1964: Proceedings of a Symposium held by the British Ceramic Research Association, P. Popper, ed., Academic Press, London, pp. 301-315 (1965)

3. Ceramics for High Performance Applications, J.J. Burke, A.E. Gorum, and R. N. Katz, eds. Brook Hill Publishing Co., Chestnut Hill, Mass. (1974)

4. Lenoe, E. M., "Recent Accomplishments and Research Needs in Structural Ceramics," in Ceramics for High Performance Applications-III: Reliability, E.M. Lenoe, R. N. Katz, and J. J. Burke, eds., Plenum Press, New York, pp. 3-18 (1979)

5. Phillips, D., C., and Davidge, R., W., "Test Techniques for the Mechanical Properties of Ceramic Matrix Fiber Composites," Br. Ceram. Trans. J., Vol. 85, pp. 123-130 (1986)

6. Schneider, S., J., and Bradley, D. R., "The Standardization of Advanced Ceramics," Adv. Ceram. Matls., Vol. 3, No. 5, pp. 442-449 (1988)

7. Schneider, S.J., Jr. "New materials, advanced ceramics and standards," Key Engineering Materials, Vol. 5355, pp. 480-485 (1991)

8. Brinkman, C.R, Quinn, G.D., McClung, R.W., "Development of ASTM Standards in Support of Advanced Ceramics Development-A Status Report,” ASME 93-GT-160, ASME International, New York (1993)

9. Quinn, G. D., “ASTM C-28: The First Decade,” Am. Ceram. Soc. Bull., Vol. 75, No. 12, pp. 45-46, December (1996)

10. Jenkins, M.G. and Quinn, G.D., "ASTM Standards for Monolithic and Composite Advanced Ceramics: Industrial, Governmental and Academic Cooperation," ASME 1996 International Gas Turbine and Aeroengine Congress and Exhibition V 5, 96-GT-270, ASME International, New York (1996)

11. Brinkman, C.R., and Quinn, G. D., "Standardization of Mechanical Properties Tests for Advanced Ceramics," in "Mechanical Testing Methodology for Ceramic Design and Reliability,” D. C. Cranmer and D. W. Richerson, eds, Marcel Decker, Inc, New York, pp. 353-386 (1998)

12. Brinkman, C.R., "Development of ASTM standards in support of advanced ceramics - continuing efforts" ASME 1998 International Gas Turbine and Aeroengine Congress and Exhibition 98-GT, ASME International, New York (1998) 
13. Freiman, S. W. and Quinn, G. D., "How Property Test Standards Help Bring New Materials to the Market," Standardization News, October (2001).

14. Salem, J.A. and Jenkins, M.G., "ASTM International Committee C28 on Advanced Ceramics: Setting standards since 1986,” American Ceram. Soc. Bull., Vol. 93, No.1, Jan (2014)

15. Committee C28, “Advanced Ceramic Sentinel,” ASTM International, West Conshohocken, Penn. (2016)

16. http://www.astm.org/COMMITTEE/C28.htm, (October 25, 2016)

17. Wilhelm, R., “Know Your Types of Standards,” Standardization New, October (2000)

18. ASTM C1161 "Standard Test Method for Flexural Strength of Advanced Ceramics at Ambient Temperature," in Annual Book of ASTM Standards, Vol. 15.01, ASTM International, West Conshohocken, Penn. (2016)

19. Quinn, G.D., Baratta, F.; “Flexure Data: Can It Be Used For Ceramics Part Design?” Advanced Materials and Processes, Vol. 1, No. 4, pp. 31-35 (1985)

20. Kanno, T., "International Standardization Activities for Fine Ceramics - Status of ISO/TC206 on Fine Ceramics," ASME paper 96-GT-321, presented at the International Gas Turbine and Aeroengine Congress and Exposition, Birmingham, U.K., June 10-13 (1996)

21. Steen, M., "European Standardization Efforts on Fibber-Reinforced Ceramic Matrix Composites," ASME 1996 International Gas Turbine and Aeroengine Congress and Exhibition Vol. 5, 96-GT-269, ASME International, New York (1996)

22. Sakaguchi, S., “Activities in ISO/TC206 Fine Ceramics” Ceramic Transactions, Proceedings of MS\&T 2016 (2016).

23. Jenkins, M. G., "Standards and Codes for Ceramic Matrix Composites," Advanced Composite Materials, Vol. 8, No. 1, pp. 55-76 (1999)

24. Lara-Curzio, E.; Jenkins, M.G., "Development of test standards for continuous fiber ceramic composites in the United States” Composites Part A: Applied Science and Manufacturing, Vol. 30, No. 4, pp. 561-567 (1999)

25. Thermal and Mechanical Test Methods and Behavior of Continuous Fiber Ceramic Composites, ASTM STP 1309, M.G. Jenkins, S.T. Gonczy, E. Lara-Curzio, N.E. Ashbaugh, and L.P. Zawada, eds., American Society for Testing and Materials, West Conshohocken, PA (1997)

26. Mechanical, Thermal and Environmental Testing and Performance of Ceramic Composites and Components, ASTM STP 1392, M.G. Jenkins, E. Lara-Curzio, S. T. Gonczy, eds. American Society for Testing and Materials, West Conshohocken, Penn. (2000)

27. Life Prediction Methodologies and Data for Ceramic Materials, ASTM STP 1201, C.R. Brinkman, and S.F. Duffy, eds., American Society for Testing and Materials, Philadelphia, Pennsylvania (1994)

28. Fracture Resistance Testing of Monolithic and Composite Brittle Materials, ASTM STP 1409, J.A. Salem, G.D. Quinn, M.G. Jenkins, eds, American Society for Testing and Materials, West Conshohocken, Penn. (2002).

29. Jenkins, M.G., "WANTED: CMC Test Standards, Design Codes for Next-Generation Nuclear Power Plants,” Am. Ceram. Soc. Bull., Vol. 85, No. 11, pp. 16-21 (2006)

30. ASTM E691 "Standard Practice for Conducting an Interlaboratory Study to Determine the Precision of a Test Method," in Annual Book of ASTM Standards, Vol. 14.05, ASTM International, West Conshohocken, Penn. (2016)

31. ASTM F2393 "Standard Specification for High-Purity Dense Magnesia Partially Stabilized Zirconia (MgPSZ) for Surgical Implant Applications,” in Annual Book of ASTM Standards, Vol. 13.01, ASTM International, West Conshohocken, Penn. (2016)

32. ASTM F2094/F2094M "Standard Specification for Silicon Nitride Bearing Balls" in Annual Book of ASTM Standards, Vol. 01.08, ASTM International, West Conshohocken, Penn. (2016)

33. Salem, J.A., “Transparent Armor as Spacecraft Windows,” J. Am. Ceram. Soc., Vol. 96, No. 1, pp. 281-289 (2013)

34. Quinn, G.D, "Does anyone know the real fracture toughness? SRM 2100: The world's first ceramic fracture toughness reference material," ASTM Special Technical Publication, n 1409, p 76-92, 2002, Fracture Resistance Testing of Monolithic and Composite Brittle Materials, J.A. Salem, G.D. Quinn, M.G. Jenkins, eds, American Society for Testing and Materials, West Conshohocken, Penn. (2002). 
35. Gettings, R.J.; Quinn, G.D.; Ruff, A.W.; Ives, L.K., "New hardness standard reference materials (SRM's) for advanced ceramics," Ceramic Engineering and Science Proceedings, Vol. 15, No. 5, pp. 817-826 (1994).

36. Quinn, G.D., Gettings, R., Ives, L.K., "A standard reference material for Vickers hardness of ceramics and hardmetals," IMEKO TC5 Conference on Hardness Measurements Theory and Application in Laboratories and Industries, HARDMEKO 2004, pp. 90-97 (2004). 